\title{
Perancangan dan Pembuatan Game "Pembelajaran Bahasa Jepang Untuk Pemula" Metode User Centered Design Berbasis Android
}

\author{
Michael Agustav ${ }^{1)}$, Kathryn Widhiyanti ${ }^{2)}$, Edwin Meinardi Trianto ${ }^{3)}$ \\ Program Studi Teknik Informatika, \\ Institut Informatika Indonesia \\ e-mail: kielmax26@gmail.com ${ }^{1)}$, kathryn@ikado.ac.id ${ }^{2)}$,edwin@ikado.ac.id ${ }^{3)}$
}

\begin{abstract}
Abstrak
Seiring perkembangan jaman dimana perdagangan bebas Asia Pasifik mulai sering terjadi, maka penduduk Indonesia perlu mempelajari bahasa lain selain bahasa Indonesia. Bahasa Jepang perlu dipelajari karena mulai banyak investor asing dari negara Jepang di Indonesia. Oleh sebab itu dibuat aplikasi sederhana untuk membantu proses pembelajaran bahasa Jepang untuk pemula menggunakan metode user centered design. Dalam metode user centered design pada pembuatan aplikasi pembelajaran aplikasi pembelajaran bahasa Jepang untuk pemula ini dilakukan dengan membuat prototype pertama berupa hand-sketches prototype, kemudia dibuat kedua berupa realisasi dari hasil hand-sketches, dan yang terakhir dibuat prototype ketiga berupa dynamic design prototype. Dari ketiga jenis prototype juga dilengkapi dengan evaluasi terhadap pengguna dan dilakukan perbaikan. Kemudian untuk pengujian telah dilakukan dua kali pengujian menggunakan metode dari usability testing yaitu completing a transaction dan evaluating the impact of subtle changes. Hasil dari kedua pengujian itu telah dianalisa dan dihitung, berdasarkan hasil analisa tersebut disimpulkan bahwa pada pengujian completing a transaction mendapatkan hasil $92,3 \%$ menunjukkan bahwa pengguna telah memahami fitur dan fungsi dari tombol yang telah disediakan pada aplikasi pembelajaran bahasa Jepang yang telah dibuat dan pada hasil pengujian evaluating the impact of subtle changes mendapatkan hasil $100 \%$ hasil tersebut menunjukkan bahwa pengguna telah dapat mempelajari bahasa Jepang dengan menggunakan aplikasi pembelajaran bahasa Jepang yang dibuat.
\end{abstract}

Kata kunci: Android, Bahasa Jepang, User Centered Design, Usability Testing, Starling, Action Script 3, Adobe Flash Builder

\begin{abstract}
With the growing rate of Asian Pacific free trading business in Indonesia, Indonesians need to be multilingual, rather than communicating only with mother language. Since recently there are quite number of investors come from Japan to Indonesia, Japanese language is fairly important to learn nowadays. And therefore this application is made to aid the process of learning Japanese for beginner by using the user centered design method. In this method the process includes making three prototypes. The first is called hand sketches prototype, then the second is the realization from the result of the first prototype, the third is
\end{abstract}

